\title{
ART DECO: THE PERIOD, THE JEWELRY
}

\author{
By J. Mark Ebert
}

Although the Art Deco period extends roughly from 1910 to well into the 1930s, it was primarily a product of the "Roaring '20s." This was a wonderfully decadent era. It was an age of Prohibition and cocktail parties, of flappers and the Charleston, of racketeers and G-men, of nouveau riche and credit spending. These were merely some of the manifestations of the social turmoil that resulted from the extreme disillusionment that followed the "war to end all wars," a violent reaction to and rejection of the strict Victorian ideals that had prevailed. Eat, drink, and be merry! The gospel according to Freud! Sexual revolution! Women were emancipatedvoting, smoking, and drinking. The "modern" woman saw herself as sophisticated, worldly, even jaded, with brazenly short skirts, plunging necklines, short hair, and the "flagrant" use of rouge, lipstick, and other cosmetics. These, then, were the times that stimulated the Art Deco movement, the period and the jewelry.

\section{ABOUT THE AUTHOR}

Mr. Ebert is president of Ebert-Richter, Inc., a Los Angeles - based buyer and supplier of diamonds and estate jewelry.

Acknowledgments: The author thanks Richter's of Palm Beach and Richter's of Nashville for the loan of a number of the pieces used to illustrate this article. Thanks are also given to Cartier, Inc. of New York City, who kindly allowed the use of several of the photographs from their book Retrospective Louis Cartier (1982).

1983 Gemological Institute of America
A rt Deco is the term applied to the design movement 1 that predominated in Europe and the United States in the 1920s and 1930s until the beginning of World War II. The earliest manifestations of Art Deco were seen around 1910, growing out of the Art Nouveau genre, but the movement established its momentum primarily during the years immediately following the First World War. Although Art Deco is commonly associated with the jewelry designed and produced during this period, the movement itself was far reaching, embracing all types of art forms, everyday commodities, and even structures.

This article examines Art Deco both in terms of the era in which the movement took hold and the distinctive jewelry that is so representative of this design style. The events that contributed to the development of Art Deco are discussed, as well as the characteristics of the fine jewelry produced during this period. Also important to any discussion of Art Deco are the materials used, the types of pieces popular at that time, and the designers who nurtured this innovative style. The movement itself virtually died with the outbreak of World War II; yet it is now undergoing a revival as one of the most unique episodes in the development of design in the 20th century.

\section{THE ORIGINS OF ART DECO}

The Art Deco movement drew inspiration from a variety of different sources (see box). However, the excitement generated by the early visits of Sergei Diaghilev's Russian Ballet to Paris (the first of which was in 1909) is widely considered to have marked the beginning of the Art Deco style. Diaghilev's production of "Scheherezade," which made its debut in 1910, is often cited as a major influence. The sets and costume designs were bold and exotic, using intensely vivid color combinations such as red and black, blue and green (Retrospective Louis Cartier, 1982); the flavor was distinctly Oriental--both exciting and inviting. 
The enthusiasm with which these revolutionary designs and color schemes were received had a significant impact on the decorative arts of the period. The influence and popularity of the Russian Ballet continued to be strong well into the 1920s. During this period, leading avant-garde artists of the day, such as Matisse and Picasso, were commissioned to work on the sets and costuming. Thus, the public was initiated, by way of the theater, into a number of important and serious art movements-expressionism, futurism, and cubism-all of which contributed to the development of the Art Deco style (McClinton, 1975).

Also during this period, the opening of King Tutankhamen's tomb (1922) produced an affinity for all things Egyptian. This influence was particularly noticeable in the decorative arts, in architecture, and in jewelry. Europe in the 1920s also saw a heightened interest in anything Negro: jazz music, American Negro dances, and African art were all in fashion.

Concurrently, many artists and designers had, albeit begrudgingly, accepted the rapid spread of industrialization and mass production. Whereas the design movements of the late 19th and early 20th centuries had been attempts to escape from this "industrial monster," the Art Deco movement was, in a sense, an attempt to form an alliance between art and industry, man and machine. For the first time, efforts were made to produce designs that could be adapted to mass production. In fact, the movement derives its name from the "Exposition des Arts Décoratifs et Industriels Modernes" (Exposition of Decorative Arts and Modern Manufacturers) held in Paris in 1925. The artistic instigators of this uneasy alliance were successful beyond their dreams. Their designs were applied to everything from toasters to ocean liners, from architecture to ceramics, from graphics to bookbinding, from furniture to jewelry. That such a distinctive style could have had such universal application is one of the fascinating aspects of the Art Deco movement.

The central theme of Art Deco was geometry, symmetry, and boldness of both design and color. Yet the movement was flexible enough to incorporate the ancillary influences of Egyptian, African, American Indian, and Oriental art as well as accommodate itself to the functionalism of industrial design. Both the spirit and affluence of the 1920s (Allen, 1931) allowed for the broad growth and development of this unique design

\section{A CHRONOLOGY OF EVENTS THAT INFLUENCED THE ART DECO MOVEMENT}

1760

1837

$1837-1901$

1867

1888

1890 s

C. $1890-1910$

c. $1901-1910$

1909

1910

$1914-1918$

1919
Beginnings of the Industrial Revolution

Tiffany opens in New York City, the first major U.S. - based jewelry firm

Victorian period (the reign of Queen Victoria of Great Britain)

Discovery of diamonds in South Africa

De Beers Consolidated Mines, Ltd. formed in South Africa

Synthetic (flame fusion) corundum appears in the marketplace

Ant Nouveau period

Edwardian period (the reign of King

Edward VII of Great Britain)

The Russian Ballet opens in Paris

The first performance of

"Scheherezade" by the Russian Ballet

in Paris

World War I

Marcel Tolkowsky's treatise on the ideal proportions of a modern brilliant cut diamond

1920 In the United States: women win the vole, Prohibition enacted, and cultured pearls appear on the market

The Earl of Carnarvon opens King

Tutankhamen's tomb

1925 The Exposition des Arts Décoratifs et Industriels Modernes is held in Paris Josephine Baker electrifies Paris in "La Revue Nègre"

1929 The U.S. Stock Market crashes

1933 Prohibition is repeated

1939-1945 World War II

1966 The commemorative exhibition "Les Années '25" is held at the Musée des Arts Décoratifs in Paris

1982

Masterworks of Art Deco" exhibit opens in Los Angeles 


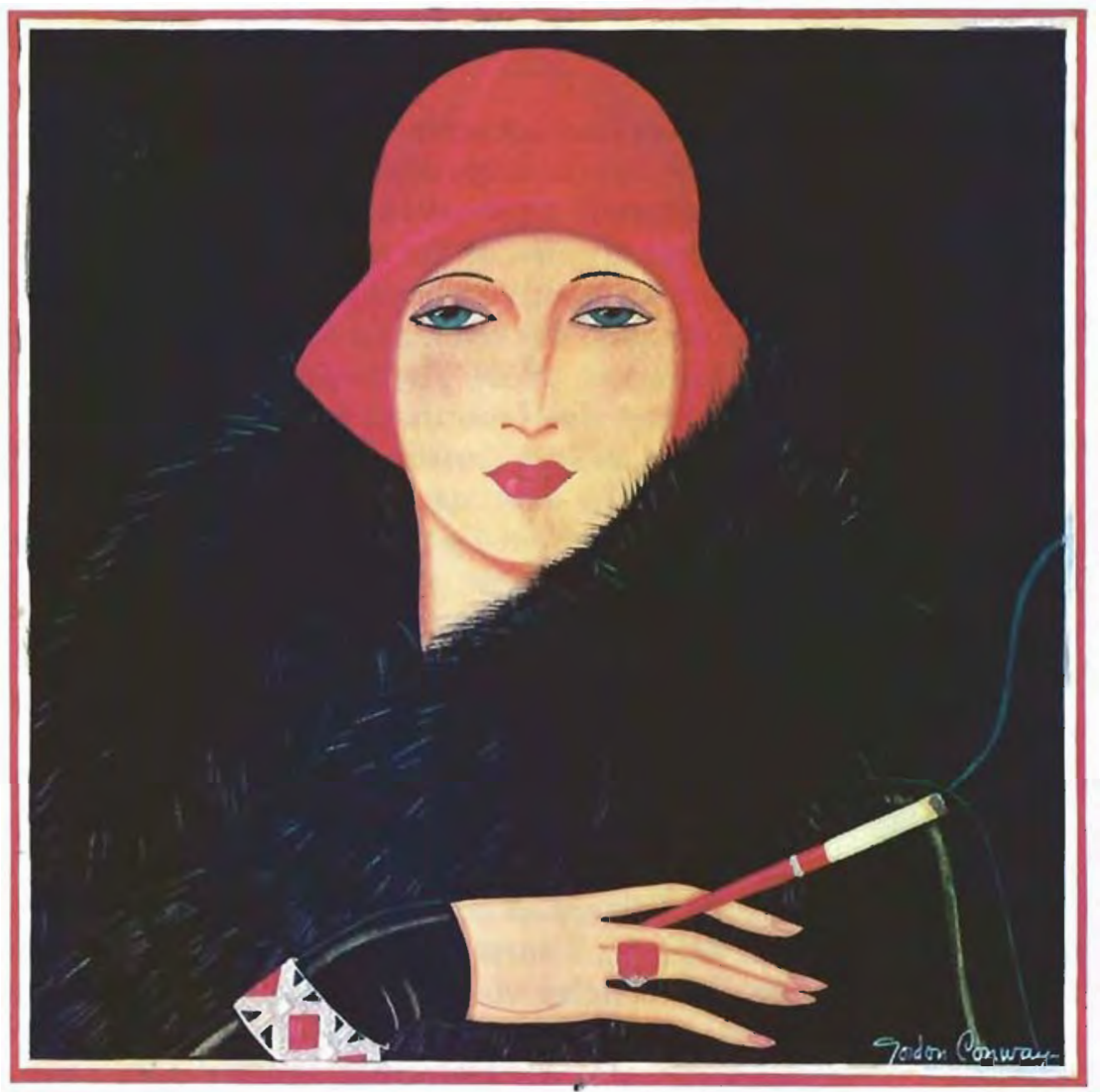

Figure 1. The sophisticated lady in The Red Hat (Gordon Conway, 1929) embodies the sleek confidence of the emancipated female of the 1920 s, the peak of the Art Deco movement. From the prints and drawings collection of the American Institute of Architects Foundation, Washington, DC. style. And in jewelry in particular, the newly emboldened female of the postwar era (figure 1) welcomed the radical designs and bold color combinations that Art Deco represented.

\section{CHARACTERISTICS OF ART DECO JEWELRY}

In fact, the art of jewelry design and jewelry making lent itself well to the philosophy and design ideals of the Art Deco movement. This becomes obvious when we study the general characteristics and specific motifs and color schemes of Art Deco jewelry. It is important to bear in mind, however, that not all jewelry that was produced in the 1920s and 1930s was of the Art Deco style, and that not all Art Deco jewelry has the same characteristics. In fact, some purists prefer to think of this period as encompassing two separate and distinct movements: Art Deco (c. 1909-1925) and Art Moderne, or Modernism (c. 1925-WWII). However, we shall treat the post-1925 influences as merely an ongoing development of an already existing style, rather than as a whole new movement: early Art Deco jewelry tends to be more graceful and feminine; later Art Deco jewelry is more austere and geometric.
The motifs of Art Deco jewelry are quite diverse. They range from the colorful "fruit salad" flower basket (figure 2) to the Egyptian scarab, from the ziggurat to the lightning bolt, from the Hollywood-style palm tree to the sleek greyhound, from the Aztec pyramid (figure 3) to various Oriental forms (figure 4). Although early Deco jewelry tends to favor the more formalized floral motifs, and the movement accommodated a wide variety of themes, the vast majority of the jewelry designs tend to be very geometric and symmetrical, reflecting the influence of cubist geometry on the movement as a whole.

Color is also important in characterizing Art Deco jewelry. The bold whiteness of platinum combined with diamond or crystal is a fundamental scheme of Deco jewelry (figure 5). Infusions of color into this scheme were generally dramatic. Black and white was a favorite combination: black onyx or black enameling with diamond or crystal or both (figure 6). The fruit salad motif represents a popular extreme of this predilection: several colored gemstones-usually ruby, sapphire, emerald, black onyx, and possibly turquoise or coral-often combined with diamonds. Clearly, Art Deco was not a subtle style. 


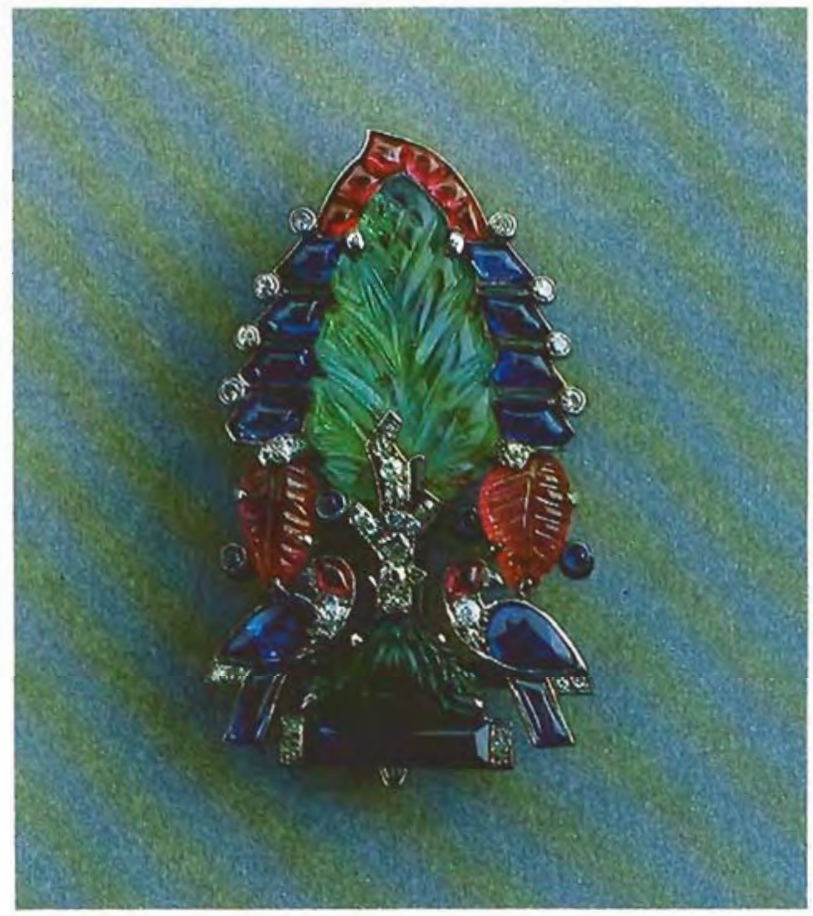

Figure 2. This Cartier brooch (1927)-with carved and cabochon emeralds, rubies, and sapphires, as well as faceted diamondsrepresents the "fruit salad" motif commonly used in Art Deco jewelry. Photo courtesy of Cartier, Inc., New York, NY.

Early Art Deco jewelry was significantly influenced by the two design periods that immediately preceded it-Art Nouveau (the "radical chic" design movement of the turn of the centuryl and
Edwardian (the conservative design style that coincided with the reign of King Edward of England, approximately 190I-1910). Early Art Deco jewelry adopted some of the more austere characteristics of the highly stylized and graceful Art Nouveau designs, but tended to formalize these motifs (Battersby, 1969). The free-flowing curves and naturalistic floral motifs of Art Nouveau became the more precise curves of perfect circles and ovals and the very stark, formalized flower representations of Art Deco. Later Art Deco jewelry was, to some extent, a reaction against the soft natural lines, pastel colors, and floral excesses of the highly feminine Art Nouveau style. The pastels were replaced by vivid colors and bold color combinations. The soft natural lines were replaced by harshly geometric and symmetrical motifs. Asymmetry and curvilinear designs were out; symmetry and rectilinear designs were in.

The Edwardian design movement was not radical like Art Nouveau or Art Deco; in fact, Edwardian jewelry was in the mainstream of conservative fashion and formal attire in the early 20 th century. Art Deco, particularly early Deco, borrowed directly from some of the more popular motifs of Edwardian jewelry: the garland, the basket of flowers, and the bow motif, to name a few. Edwardian jewelry influenced Art Deco jewelry in two other significant ways: (1) it provided the basis for the materials that would be used in Deco jewelry, and (2) it introduced the techniques with which these materials would be worked (Becker, 1980). Edwardian jewelry was made primarily with

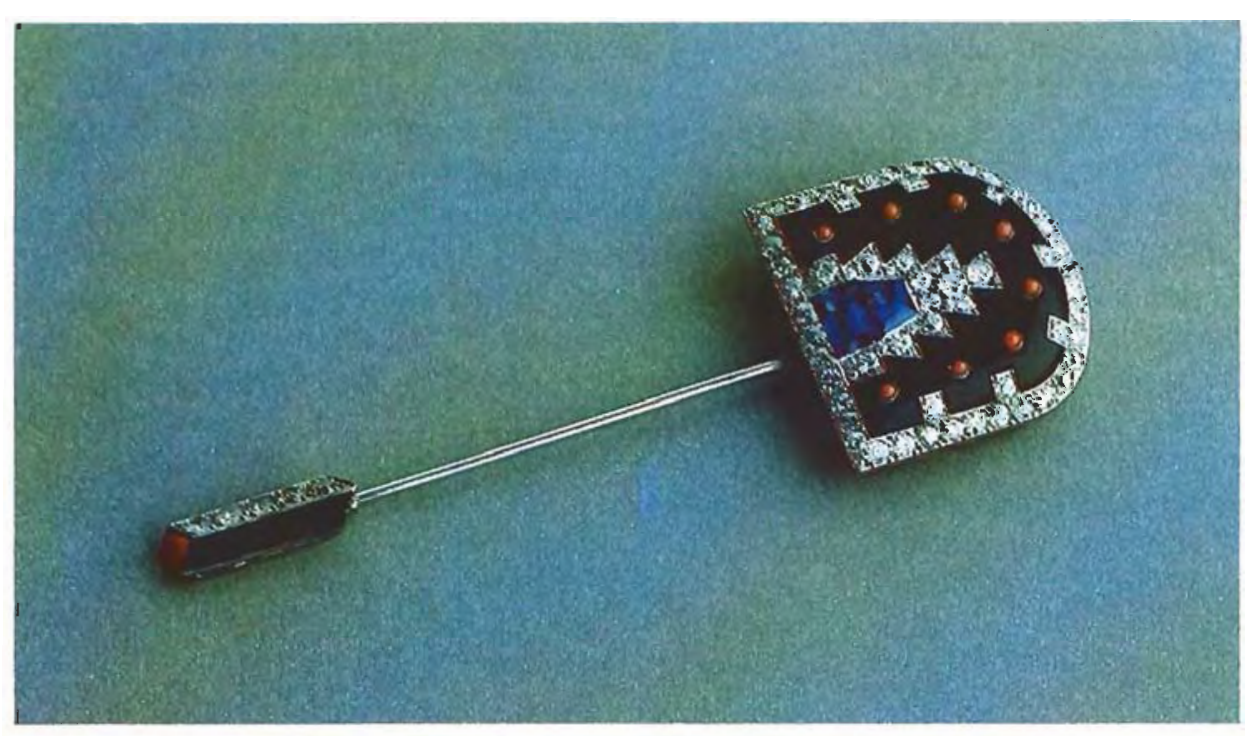

Figure 3. The pyramid design on this jabot pin by Cartier (c. 1920) was a popular motif of Art Deco jewelry. The sapphire, black onyx, diamond, coral, and platinum used serve to illustrate the bold color combinations of the period. The pin measures $10.2 \times$ $2.3 \mathrm{~cm}$. Photo courtesy of Cartier, Inc., New York, NY. 
diamonds and platinum-numerous small diamonds mounted in an invisible setting of platinum, using "knife wire" setting and millegraining techniques with precise open-work designs. Art Deco jewelry designers used these materials and setting techniques as a starting point in their styles.

\section{MATERIALS USED IN ART DECO JEWELRY}

As mentioned above, the basic materials used in fine or precious Art Deco jewelry were platinum and diamonds. Platinum was favored for three main reasons: its great strength /thus enabling a gem to be securely set with a minimal amount of metal), its lasting high luster (resistance to tarnish) and its malleability (enabling the implementation of designs with precise and intricate shapes and outlines). White and even yellow gold were often used as more affordable alternatives during the Depression years of the 1930s.

Diamond was the gemstone of the period, and it was used in a variety of ways. Large solitaires were very much in vogue, as were items made from numerous small diamonds. The "knifewire" and millegrain setting techniques of the Edwardian period eventually gave way to pavé setting. Early in this period, Tolkowsky (1919) published his dissertation on the "proper" proportions of a modern round brilliant-cut diamond, and, although most of the diamonds used in Deco jewelry were what are now considered "Old European" cuts, they were often "well cut" Old Europeans. Probably because of the cubist or geometric influence in the design of Art Deco jewelry, new cuts or shapes of diamonds were being discovered, implemented, and popularized: baguettes and emerald cuts, triangles and shield cuts, and pear and marquise shapes, to name a few.

Colored gemstones also played an important role in Art Deco jewelry. The most popular of these were rubies, sapphires, and emeralds, although just about any and all colored gems were used (e.g., black onyx, rock crystal quartz, jade, turquoise, coral, and mother-of-pearl). When worn as center stones, these gems were usually of fine quality and faceted. As accent stones, colored gems appeared in the form of cabochons, carved leaves or calibré-cuts (again, see figure 2).

The use of flame-fusion synthetic corundum (both synthetic ruby and synthetic sapphire) was

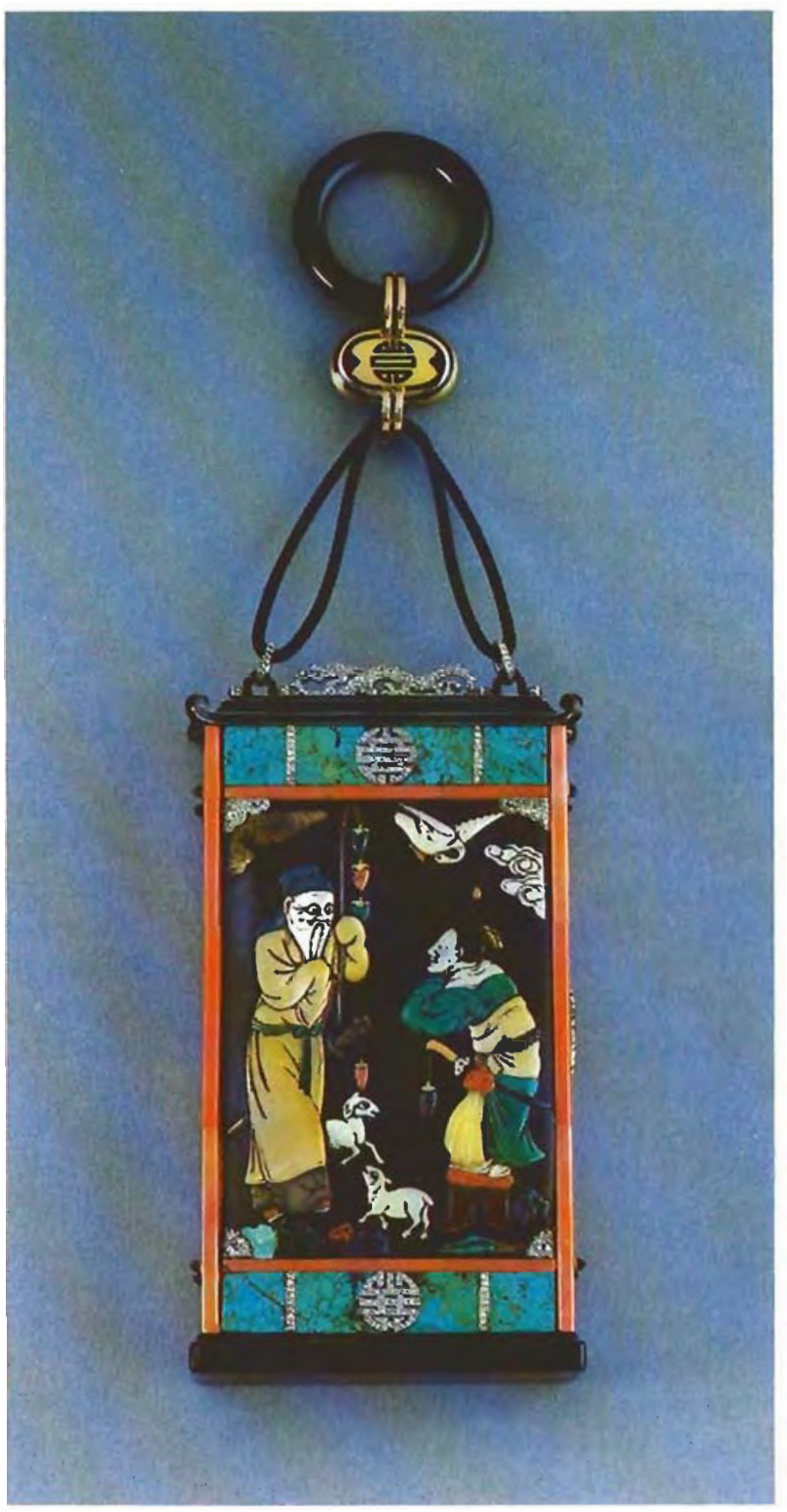

Figure 4. This minaudière by Cartier (1924) demonstrates the era's fascination with strong colors and Oriental motifs. Made from paneled wood and gold, this piece is encrusted with jewels and enamel work. It measures $12.1 \times 6$ $\times 1.9 \mathrm{~cm}$. Photo courtesy of Cartier, Inc., New York, NY.

also widespread. We do not know whether such synthetics were originally used to deceive, to increase the ease in matching size or color, or perhaps simply because of the limited gem identification techniques available at that time. 
Figure 5. Bracelets were particularly popular during the Art Deco era. Typical is this wide flexible bracelet of diamond (approximately

25 ct total weight) and

platinum. Photo by Tino Hammid. Bracelet courtesy of Richter's of Palm Beach.

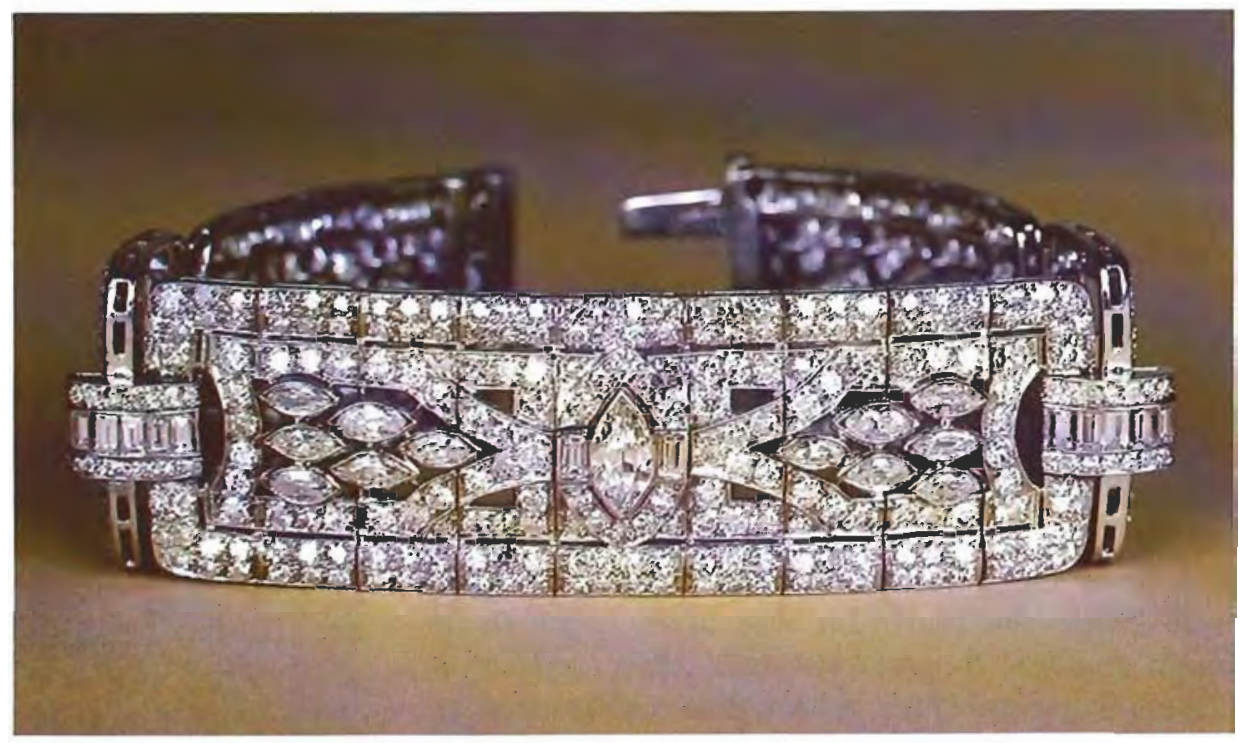

Frequently, however, an exquisite Art Deco piece will be found to contain synthetic accent stones.

Pearls-both natural and cultured-played a prominent role in the jewelry of this period. Cultured pearls were first successfully marketed on a large scale during the 1920s and quickly became very fashionable. Pearls were used in a variety of ways: in chokers or long strands, as a contrast to colored gems (figure 7), to complement diamonds, and in the ever-popular sautoir.

Enameling was also prominent in Art Deco jewelry, although it was much less popular than it was during the Art Nouveau period. Cloisonné was the most common type of enameling used, with red and black being the most popular colors (again, see figure 4). This use of enameling probably resulted from the Oriental influence on Art Deco as well as the carryover from Art Nouveau.

No discussion of the jewelry of the Art Deco period would be complete without making mention of costume jewelry. The famous French couturière Coco Chanel is credited with making costume jewelry not only acceptable, but also chic (Becker, 1980). The popularity of costume jewelry during the Art Deco period prompted a number of innovations in jewelry materials. For example, advancements made in the field of plastics, particularly the use of bakelite plastic, were adapted to costume jewelry. Various types of imitation pearls also became popular. Other materials often

Figure 6. The bold black and-white color scheme favored by many Art Deco designers is evident in this platinum, diamond (about 2 ct total weight), crystal, and black onyx bow pin.

Photo by Tino Hammid. Pin courtesy of Richter's of Nashville.

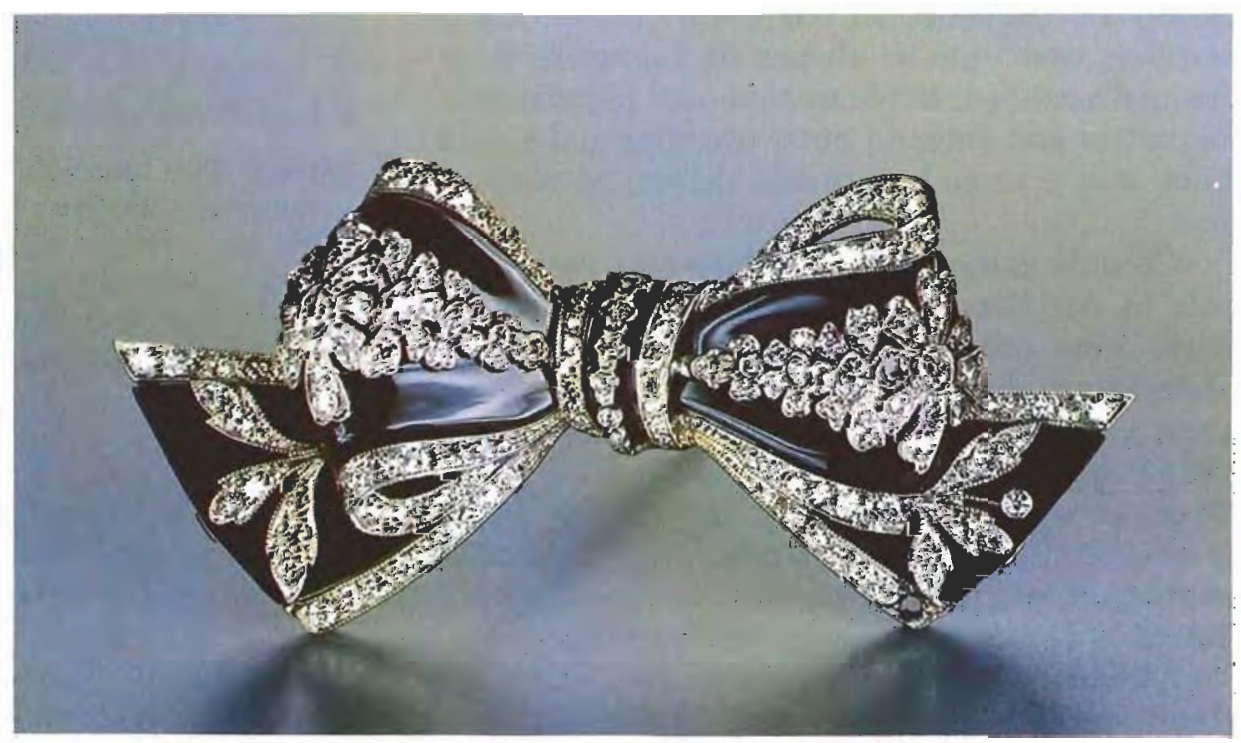




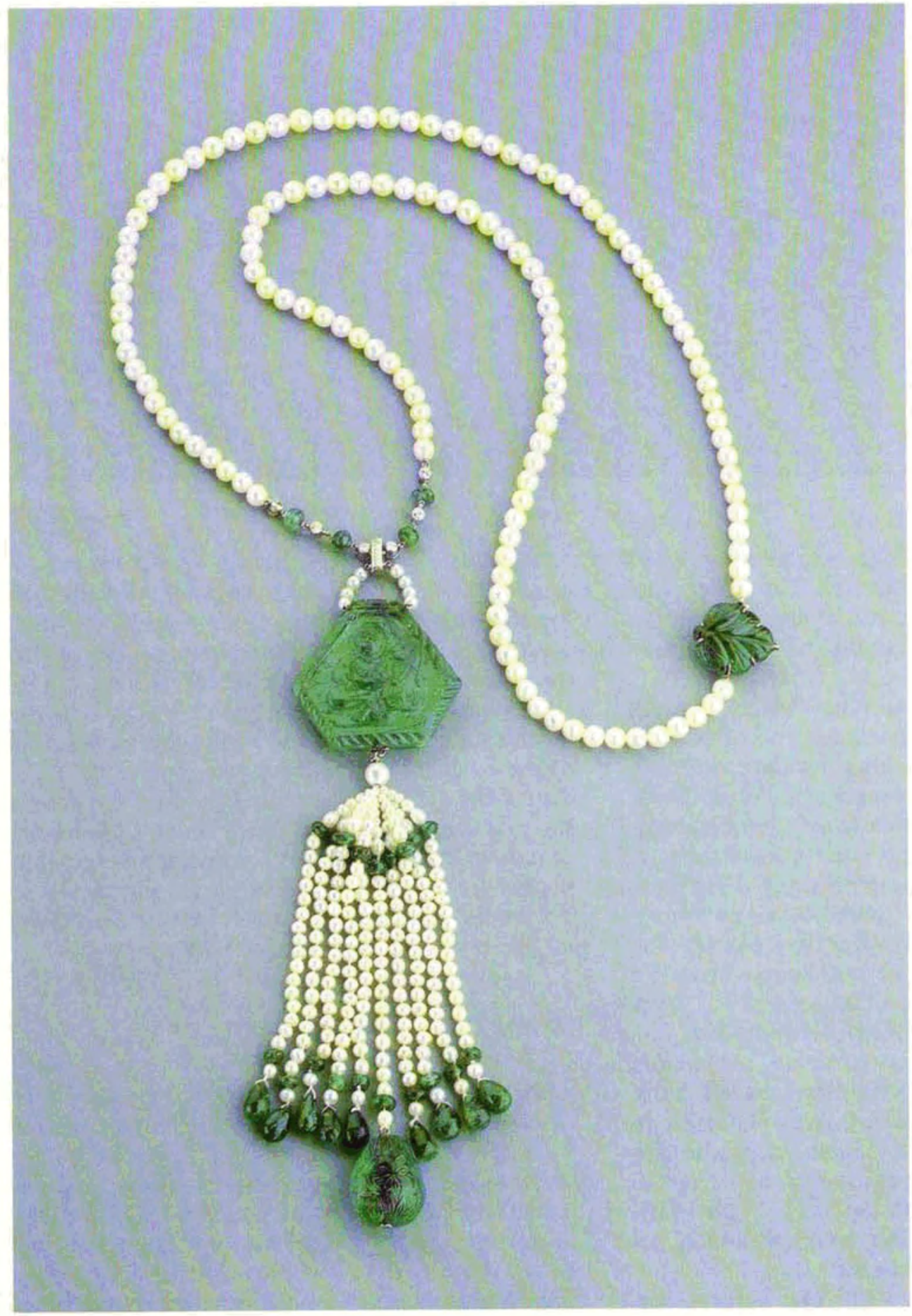

Figure 7. Pearls, diamonds, and emeralds provide a striking combination in this Oriental-motif necklace by Cartier (c. 1925). The hexagonal carved emerald pendant weighs $86.71 \mathrm{ct}$. Photo courtesy of Cartier, Inc., New York, NY.

used in costume jewelry include aluminum, chrome, marcasite, glass, and rhinestone. It is interesting to note that for the most part during this period the public did not regard these costume jewels as cheap imitations, but rather as "frankly fake" ornaments: fun, daytime jewelry. When, in the 1930s, they began to be viewed and used merely as direct imitations, they quickly lost their popularity.

\section{POPULAR TYPES OF ART DECO JEWELRY}

The specific types of jewelry that are highly favored or, conversely, assiduously shunned during a particular era often reflect the sentiments of that period. During the Art Deco era, gone were the cameos, chatelaines, tiaras, diadems, and many other pieces typical of the Victorian period that dominated the 19th century (Flower, 1951). The 
Figure 8. A typical item of the Art Deco period is the double-clip brooch. This platinum, diamond (approximately 7 ct total weight), and blue sapphire brooch is a good example both of this type of jewelry and of the use of bold, contrasting colors. Note the symmetry of the brooch: if the piece were bisected horizontally or vertically, each half would be a mirror image of the other. Photo

by Tino Hammid. Brooch courtesy of Richter's of Nashville.

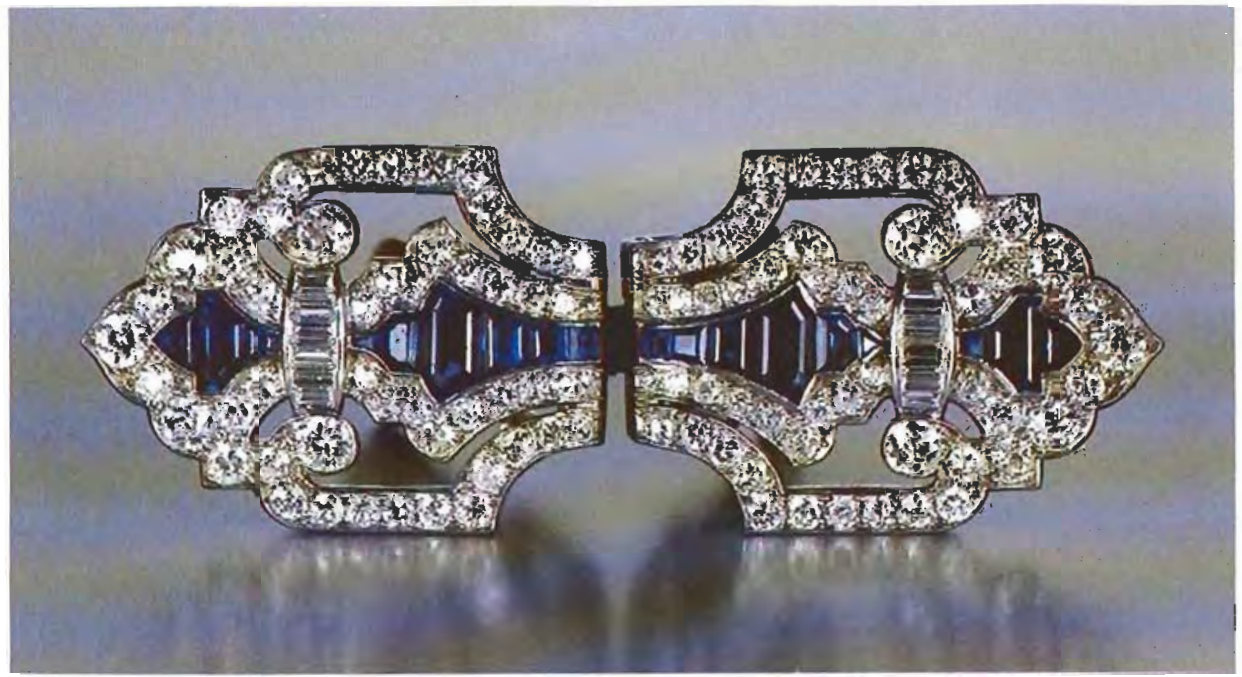

liberated woman of the 1920 s wanted no relics of the repressed Victorian female. The short hair styles popular during this period also signaled an abrupt end to ornate hair combs and large hat pins (Lesieutre, 1974).

The plunging necklines of the 1920s lent themselves well to long pendants and other long necklaces. The sautoir, a long necklace made up of numerous strands of pearls or colored beads, and ending with one or two tassels, was particularly fashionable. The short hair styles, which exposed the ears, favored ornate earrings, often long, jeweled, and dangly. The short-sleeved or sleeveless dresses paved the way for a flood of bracelets and a variety of bracelet styles. Bangle bracelets became very popular and often were even worn on the upper arms. Flexible platinum and diamond bracelets were also extremely fashionable (Arwas, 1980), with styles ranging from the thin, single straight row of diamonds in platinum to the wide (up to two inches, $5 \mathrm{~cm}$ ) platinum and diamond styles that often contained more than 25 ct of diamonds (again, see figure 5). These platinum and diamond bracelets were frequently accented with colored gemstones.

Perhaps the item of jewelry that is most typical of this period is the double-clip brooch (figure 8). The two identical clips could be attached together and worn as a single brooch, but more frequently they were worn separately as decorative clips on the lapels or belt of a dress or on the everpopular cloche hat. Also particularly popular during this period was the jabot pin (see figure 3).

Wristwatches became increasingly fashionable during the Art Deco era. Usually they were made in platinum and pavé set with diamonds and other accent stones or enameling (figure 9).
Also popular were long-chained pendant watches and lapel watches, suitably jewel encrusted. The French firm of Cartier is appropriately credited with the design and manufacture of some of the most exquisite time pieces of this period.

As the cocktail party became the popular form of entertaining, so did the cocktail ring become a particularly fashionable piece of jewelry. Also during the 1920s, some normally mundane accessories became indispensable jewels for the woman of fashion. Articles such as compacts, minaudières (again, see figure 4), cigarette cases, and cigarette holders were often elaborately jeweled symbols for the liberated woman of the era.

\section{IMPORTANT DESIGNERS OF ART DECO JEWELRY}

Although a great deal of Art Deco jewelry was mass produced, the finest jewels of this period were individually designed and hand crafted by some of the most famous jewelry houses and independent designers of all time. A great number of these were found in Paris. It is generally believed that the Art Deco movement originated in France and achieved its greatest creativity there, whereas the movement was popularized and the jewelry mass produced in the United States. René Lalique, who is known primarily for his Art Nouveau jewelry and objets d'art, was also an important designer of Art Deco jewels. His designs were mainly of the early Art Deco style, and he worked primarily in colored transparent glass, rock crystal quartz, and enameling. Several other leading designers also managed to survive the transition from Art Nouveau to Art Deco. Henri Vever, Paul Brandt, and Georges Fouquet are among those 
who made significant contributions to both of these major design movements.

The list of important French designers and jewelry houses that were both innovative and prolific in the Art Deco style is too long to discuss each one in detail. Jean Fouquet (the son of Georges Fouquet), Gérard Sandoz, Raymond Templier, Jean Desprès, Mauboussin (particularly in the early Deco motifs), Boucheron, Van Cleef \& Arpels (a relatively young firm at the time), Lacloche, Chaumet, and, as mentioned earlier, Louis Cartier (who specialized in clocks as well as the wristwatches he popularized) are but a few of the many important French names in Art Deco jewelry (Lesieutre, 1974).

However, not all of the leading Art Deco jewelers were French. Georg Jensen, a Danish silversmith and sculptor, produced some very creative jewelry and silverware designs. He worked primarily in silver and less expensive gemstones, and his designs tend to reflect the early Deco style. There were also some important American jewelry houses, foremost among which was Tiffany and Co. Tiffany produced some highly stylized Art Deco jewelry as well as a number of clocks and objets d'art. Black, Starr and Frost as well as Marcus and Co. also made significant contributions'to the Art Deco style.

Luckily for the collector or appreciator of the fine jewelry of the Art Deco period, many of the designers signed their pieces. However, it does not follow that a signed piece of Art Deco jewelry is necessarily fine and desirable and an unsigned piece less fine or less desirable. Often the converse is true. The finest of Art Deco jewelry combines the finest gemstones available, the best workmanship, and the most interesting designs.

\section{CONCLUSION}

With the onset of the Depression, both the demand for fine jewels and the creative spirit necessary to stimulate innovative designs in jewelry were significantly weakened. The outbreak of World War II-when by necessity function replaced form-signaled an abrupt end to the Art Deco era. Although there was an attempt in the 1940s to revive this creative spirit, it was short lived. To this day, there has been no design movement as all-pervasive, enduring, or creative as Art Deco. Yet interest in the Art Deco period essentially lay dormant until the 1960s, when its revival was highlighted by the commemorative exhibition "Les Années '25" at the Musée des Arts

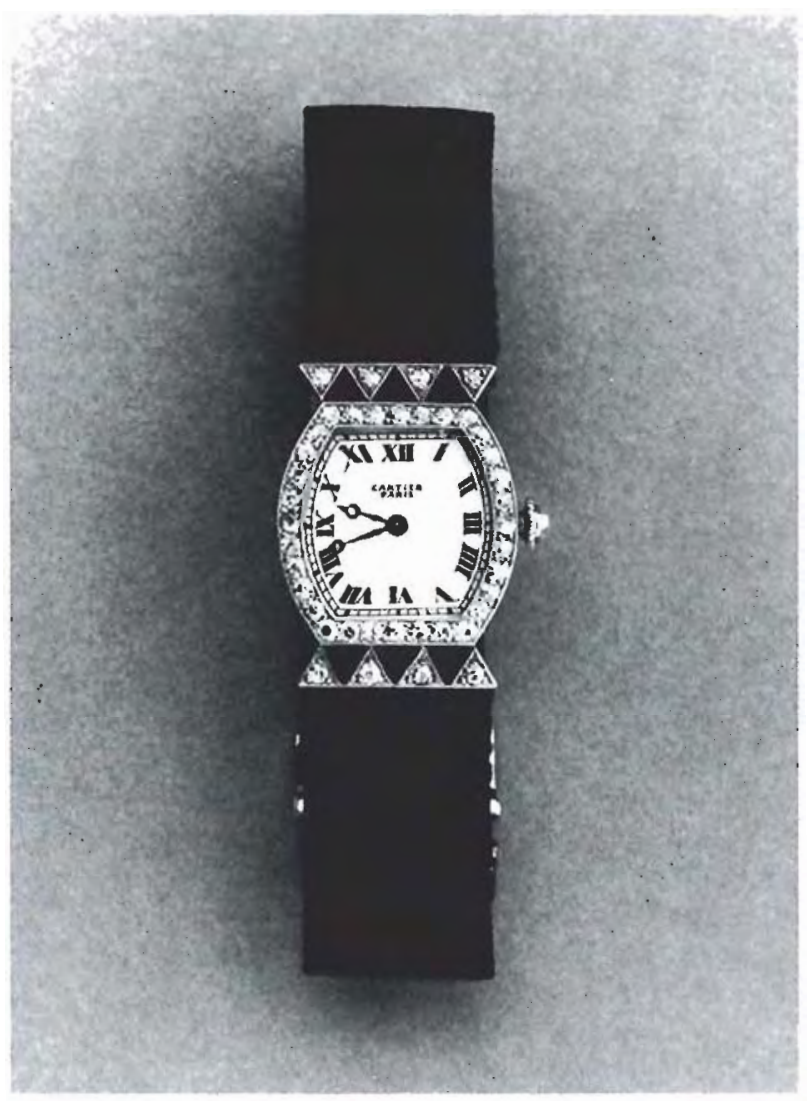

Figure 9. Wristwatches gained popularity during the Art Deco era; diamonds and platinum were typical decorations. Photo courtesy of Cartier, Inc., New York, NY.

Décoratifs in Paris. Even today, the popular appeal of this distinctive art form is evident in the response to the "Retrospective Louis Cartier" exhibit of Art Deco jewelry and time pieces held in Los Angeles earlier this year.

\section{REFERENCES}

Allen F.L. (1931) Only Yesterday. Harper \& Brothers, New York.

Arwas V. (1980) Art Deco. Harry N. Abrams, New York.

Battersby M. (1969) The Decorative Twenties. Walker \& Co, New York.

Becker V. (1980) Antique and Twentieth Century Jewellery. NAG Press, London.

Flower M. (1951) Victorian lewellery. Duell, Sloan and Pearce, New York.

Lesieutre A. (1974) The Spirit and Splendor of Art Deco. Paddington Press, New York.

McClinton K.M. (1975) Art Deco: A Guide for Collectors. Clarkson N. Potter, New York.

Retrospective Louis Cartier (1982). Cartier, New York.

Tolkowsky M. (1919) Diamond Design. E. \& F.N. Spon, Ltd. London. 